\title{
INTERNALISASI NILAI PENDIDIKAN UKHUWAH ISLAMIYAH, MENUJU PERDAMAIAN (SHULHU) DALAM MASYARAKAT MULTIKULTURAL PERSPEKTIF HADIS
}

\author{
Ali Ridho \\ Dosen STAI Al-Khairat Pamekasan \\ Aldo.okfor@gmail.com
}

\begin{abstract}
This Paper used library research approach that aimed to answer the phenomena that happened this era that paid attentions to the peoples that break the brotherhood. In the politic issue at Jakarta, created dualism between one community to others, diversity become headline issue and instrument/tool of power. While Jakarta as the capital of Indonesia being prototype and indicator of the human adolescent index of state. Multiculturalism interpretation being in hesitate when talked about politic and poverty. Demonstrations and peace refused non muslim being headline and viral. This paper concluded that to make a peace (shulhu), brotherhood (ukhuwah) should constructed as well as the prophetic message that ukhrawi minded. Because the brotherhood now a day already had been broke by the materialism and pragmatism. In Islam the concept of Brotherhood education is how to strength and organizing a hearth (tandzim al-qolb) and love the people by the name of Allah, through three parts of brotherhood (ukhuwah); Ukhuwah Islamiyah, Ukhuwah Wathaniyah, dan Ukhuwah Basyariyah.
\end{abstract}

Keywords: Education of ukhuwah Islamiyah, Peace (shulhu), Multicultural people

\begin{abstract}
Abstrak
Tulisan ini menggunakan pendekatan pustaka (library) dan bertujuan untuk menjawab sebuah fenomena yang terjadi akhir-akhir ini yang menyedot energi masyarakat, yang memecah belah tali persaudaraan (ukhuwah). energi yang seharusnya digunakan untuk hal yang positif namun beralih pada hal-hal yang negatif. Dalam kontestasi politik di Jakarta, kompleksitas dualisme kelompok terlihat terang benderang, hitrogenitas etnis dan isu agama menjadi instrument untuk mencapai tirani dan kekuasaan. bagaimana Jakarta sebagai ibu kota Indonesia menjadi barometer dan indikator tingkat etika kedewasaan masyarakat bangsa dalam sebuah Negara. Tafsir Multikulturalisme untuk mencapai kesadaran majmuk menerima perbedaan menjadi keraguan dan tanda tanya ketika berhadapan dengan isu politik dan kekuasaan. Aksi damai menolak pemimpin non muslim membanjiri jalan memenuhi Monumen Nasional menjadi viral dan menjadi konsen utama (headline) insan jurnalisme yang berhari-hari. Tulisan ini berkesimpulan bahwa, untuk mencapai perdamaian (shulhu), persaudaraan (ukhuwah) harus dikontruksi sesuai dengan pesan profetik yaitu harus bertendensi ukhrawi. Karena tidak bisa dipungkiri persaudaraan yang terjalin pada zaman saat ini justru lebih materialistik pragmatis. Dalam Islam, konsep Pendidikan
\end{abstract}


Ukhuwwah adalah meluruskan hati (tandzim al-qolb) serta mencitai saudara kita hanya karena Allah, dengan tiga bentuk Persaudaraan (ukhuwah); Ukhuwah Islamiyah, Ukhuwah Wathaniyah, dan Ukhuwah Basyariyah.

Kata Kunci: Pendidikan ukhuwwah Islamiah, Perdamaian (shulhu), Masyarakat Multikultural

\section{A. PENDAHULUAN}

Islam adalah agama universal yang ajarannya ditujukan bagi umat manusia secara keseluruhan, inti ajarannya selain memerintahkan penegakan keadilan dan juga meletakan pilar-pilar perdamaian yang diiringi dengan himbauan kepada umat manusia agar hidup dalam suasana persaudaraan dan toleransi tanpa memandang perbedaan ras, suku, bangsa dan agama, karena manusia pada awalnya berasal dari asal yang sama. Firman Allah, Q.S. An-Nisa': 1

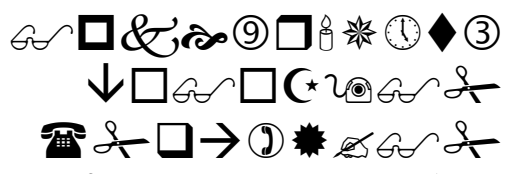

8d)八 G of Kश

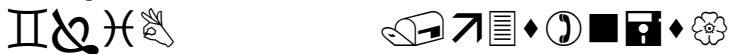

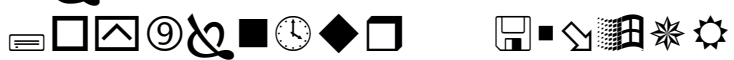

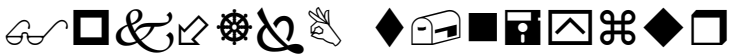

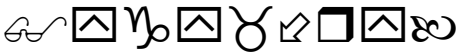

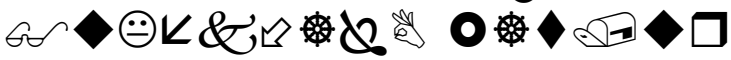
\&

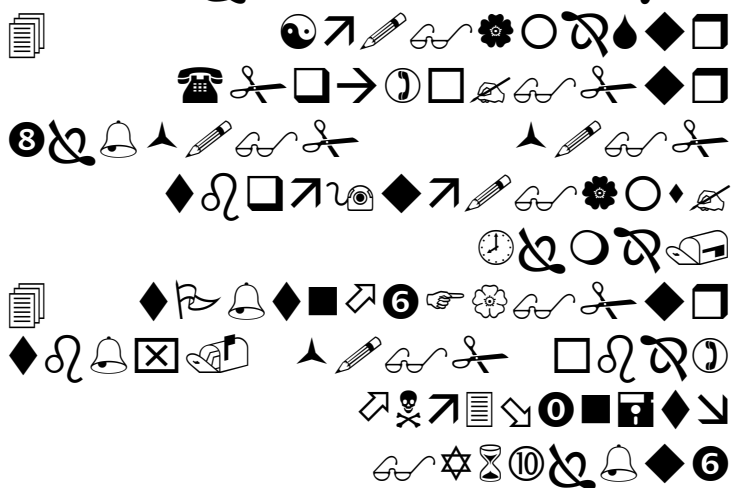

Artinya:

Hai sekalian manusia, bertakwalah kepada Tuhan-mu yang Telah menciptakan kamu dari seorang diri, dan dari padanya Allah menciptakan isterinya; dan dari pada keduanya Allah memperkembang biakkan laki-laki dan perempuan yang banyak. dan bertakwalah kepada Allah yang dengan (mempergunakan) nama-Nya kamu saling meminta satu sama lain dan (peliharalah) hubungan silaturrahim. Sesungguhnya Allah selalu menjaga dan Mengawasi kamu.

Melalui ajaran dan pilar tadi, Islam mendorong para pengikutnya agar bersikap aktif dalam upaya menjalin ukhwah dengan pengikut agama terutama sesama muslim. Hal ini Allah menjelaskan lebih lanjut tentang persaudaraan dalam ayatnya al-Hujarat: 10 yang artinya:

Orang-orang beriman itu Sesungguhnya bersaudara. sebab itu damaikanlah (perbaikilah hubungan) antara kedua saudaramu itu dan takutlah terhadap Allah, supaya kamu mendapat rahmat.

Persaudaraan ini merupakan konsekwensi dari keberadaan keimanan sesorang. Karena ini merupakan hak orang muslim terhadap muslim yang lain demi mendapat rahmat Allah, rahmat Allah disini bisa berarti perdamaian dan kedamaian lingkungan dan terlebih dari itu adalah kedamainan batin.

Menjalin persaudaraan sesama muslim sangat penting artinya, karena dengan ikatan persaudaraan akan diperoleh persatuan. Dengan adanya persatuan dapat diraih kekuatan. Jika persatuan dan kekuatan telah dimiliki oleh umat Islam maka segala apa yang menjadi hajat hidup kaum muslimin Insya Allah dapat diwujudkan, selain itu syi'ar Islam juga 
akan lebih terasa, karena di setiap daerah muslim akan terdapat kegiatan kegiatan syi'ar Islam, misalnya, dengan banyak pembangunan masjid, madrasah, dan pondok pesantren akan menambah semarak kehidupan keagamaan masyarakat.

Melihat kondisi saat ini, tali persaudaraan antar kaum muslimin sudah mulai pudar, bahkan bisa dikatakan pudar, apalagi antar lintas agama. Menilik dari berbagai kejadian yang terjadi di negeri ini, mulai dari kasus Ansor dengan Khalid Basalamah, konflik lintas agama, muslim dengan non muslim, hal ini terlihat adanya ukhuwwah yang putus, padahal mereka sama-sama beragama Islam, dan samasama hamba Allah SWT.

Situasi yang kaum muslimim Indonesia seakan terpolarisasi ke dalam sebuah kelompok agree and disagree bahkan fenomenana saling hujat merupakan satu hegemoni ${ }^{1}$ yang kemudian muncul dengan berbagai tafsir hermenitik yang memunculkan sikap klaim pembenaran kelompoknya dan menyalahkan kelompok lain dan pada gilirannya mnegikis nilai persaudaraan antar ummat beragama Tulisan ini akan mengupas tentang tali persaudaraan (ukhuwwah) khususnya ukhwah Islamiyah dalam upaya memberikan solusi dari kondisi yang sudah sangat melanggar dari aturan-aturan yang digariskan oleh agama Islam.

${ }^{1}$ Dalam filsafat Antonio yaitu kontruksi dan merasuknya dalam suatu sistem nilai dan kepercayaan yang menopang suatu kelas yang berkuasa. Hegemono juga berarti memasukkan nilai-nilai dan kepercayaan dari kelompok sosial lainnya yang bukan dari kelompok yang dominan, baca H.A.R. Tilaar, Multikulturalisme; Tantangan Global Masa Depan dalam Tranformasi Pendidikan Nasional (Jakarta : PT Gramedia Widiasarana Indonesia, 2004), h. 385
Dari penjelasan di atas, setidaknya ada beberapa masalah yaitu adanya polarisasi yang menciptakan distingsi sosial yang merusak nilai persaudaraan (ukhuwah) baik antar agama maupun antar sekte dalam Islam sendiri.

\section{B. KAJIAN TEORI}

Konsep dan teori pendidikan nilai ukhuwwah menurut Nurkholis Madjid yang menurut penulis merupakan konsep yang relevan dan konsepsi persaudaraan saat ini di mana Nurkholis mengkorelasikan keimanan dengan rahmat Allah (al-Imanu bi rahmatillah) serta antara rahmat Allah dengan jiwa persaudaraan (wa rahmatullah bi alUkhuwwah). Menurutnya, kaum beriman adalah (seharusnya) bersaudara. Persaudaraan itu adalah bentuk paling penting dari ikatan cinta kasih (silaturrahim) atau ukhwah basyariyah antar sesama manusia, sehingga segala permasalahan dan perbedaan tidak akan menjadi problem dan menjadi kendala bagi kemanusiaan. $^{2}$

Konsep inilah yang menurut paham penulis akan menjadi sumber perdamaian jika dijadikan suatu landasan dalam pendidikan berukhuwah. Yaitu menjaga hubungan baik dengan mengharap ridha Allah SWT yang senantiasa berbanding lurus dengan keimanan kepada Allah dan menjaga hubungan antara sesama dengan sebuah paham realitas pluralitas yang menjadi sunnatullah. Sehingga perdamaian (shulhu) menjadi solusi yang dapat diambil oleh manusia dalam konflik atau fenomena kekerasan yang tidak dibenarkan oleh Islam melalui landasan hadis dan nilai-nilai

2 Nurcholish. Madjid, Masyrakat Religius, (Jakarta: Paramadina, 2000), h. 29 
universalitas (rahmatan lilalamin) yang diajarkan oleh Rasulullah SAW.

Zahid Aziz dalam bukunya yang berjudul "Islam peace and tolerance" menegaskan bahwa Islam adalah agama yang mengdepankan nilai shulhu (perdamaian) dan toleransi (tasamuh) dalam ajaran yang dibawakan Muhammad. Dalam periode Madinah terdapat beberapa praktek pendidikan dan kebijakan rasululah yang mengakomudir semua suku, termasuk Yahudi untuk kemudian saling bekerja sama dan bersatu dalam meningkatkan kualitas ekonomi, bisnis perdagangan, politik dan sosial yangdilakukan Rosulullah dengan mengedepankan perdamaian dan toleransi sebagai bentuk menjaga persaudaraan antar masyarakat Madinah. ${ }^{3}$

Dengan demikian perdamaian (shulhu) merupakan suatu nilai pendidikan dalam Islam yang dicontohkan Nabi di dalam merekatkan ummat dan mempersatukan realitas perbedaan suku, ras, etnis dan agama yang sejatinya dapat diterapkan di Indonesia sebagai Negara kebhinekaan dan menganut sistem demokrasi $^{4}$ dengan mengedepankan musyawarah dan menghormati segala perbedaan.

Masyarakat multikultural berarti "keberagaman budaya". Sebenarnya ada tiga istilah yang sering digunakan untuk menggambarkan masyarakat yang mempunyai keberagaman tersebut (agama, ras, bahasa, dan budaya yang berbeda) yaitu pluralitas (plurality), keragaman (diversity), dan multikultural

3 Zahid Aziz, Islam peace and tolerance (Ahmadiyya Anjuman Lahore Publications, U.K. 2007), h. 5-7

${ }^{4}$ Lihat Mufiqur Rahman, Demokrasi dalam Filsafat Pendidikan Islam dan Barat, (Malang: Unisma 2017). h. 8. (multicultural). Ketiga ekspresi itu sesungguhnya tidak merepresentasikan hal yang sama, walaupun semuanya mengacu kepada adanya 'ketidaktunggalan'.8 Inti dari multikulturalisme adalah kesediaan menerima kelompok lain secara sama sebagai kesatuan, tanpa memperdulikan perbedaan budaya, etnik, jender, bahasa, ataupun agama. Apabila pluralitas sekedar merepresentasikan adanya kemajemukan (yang lebih dari satu).

Diversitas dalam masyarakat menurut Bikhu Parekh bisa dikategorikan dalam tiga hal. Pertama, perbedaan subkultur (subculture diversity), yaitu individu atau sekelompok masyarakat yang hidup dengan cara pandang dan kebiasaan yang berbeda dengan komunitas besar dengan sistem nilai atau budaya pada umumnya yang berlaku. Kedua, perbedaan dalam perpektif (perspectival diversity), yaitu individu atau kelompok dengan perpektif kritis terhadap mainstream nilai atau budaya mapan yang dianut oleh mayoritas masyarakat di sekitarnya. Ketiga, perbedaan komunalitas (communal diversity), yakni individu atau kelompok yang hidup dengan gaya hidup yang genuine sesuai dengan identitas komunal mereka (indigeneous people way of life). ${ }^{5}$ Hal ini sesuai dengan teori Furnifall (1991) masyarakat Multikultural terdiri dari dua atau lebih dalam sub-sub sistem. ${ }^{6}$

\section{PEMBAHASAN}

1. Arti Ukhuwah (persaudaraan)

Arti Saudara dalam Kamus besar bahasa Indonesia adalah orang yg seibu seayah (atau hanya seibu atau seayah saja);

5 Tri Astutik Haryati, Islam Dan Pendidikan Multikultural (Tadrîs. Volume 4. Nomor 2. 2009), 156.

6 Bambang Rsutanto, Masyarakat Multikultural di Indonesia (Bandung: PT Remaja Rosdakarya, 2016), h. 40. 
adik atau kakak; orang yg bertalian keluarga, sanak famili. ${ }^{7}$ Jadi Persaudaraan adalah sebuah ikatan atau sebuah perpaduan dari dua orang ataupun lebih yang serupa dengan talian saudara.

Dalam hal ini, Persaudaraan dalam Islam yang biasa disebut dengan Ukhwah Islamiyah adalah upaya mencurahkan cinta yang tulus dan pembelaan terhadap kebenaran, sesakit sepenanggungan dalam menuju cita-cita dan saling tolong menolong dalam mengatasi segala persoalan hidup ${ }^{8}$.

Al-Qurtubi dalam hal ini beracuan terhadap hadis Nabi :

$$
\text { وكونوا عبادالله إخوانا }
$$

Artinya:

"dan jadilah kamu hamba-hamba Allah yang bersaudara"

Pengertian persaudaraan dalam hadis tersebut menurut Qurthubi berusahalah agar kamu menjadi saudara senasab dalam kasih sayang, tolong menolong, saling membantu dan memberi nasihat.

Dalam berbagai definisi ini, masuk pada esensi keberadaan manusia yang tidaklah bisa hidup sendirian. Seseorang membutuhkan adayanya faktor ataupun kehidupan lain demi menopang dinamisasi kehidupannya, maka terkait dengan definisi tersebut ada sebuah hadis nabi yang memberiakn justifikasi bagi pemersatu tali persaudaraan dengan kasih dan cintanya serta claim termasuk golongan tidak beriman bagi orang yang tidak mengasihi sesama:

${ }^{7}$ Kamus Besar Indonesia, tt,

${ }^{8}$ Yusuf Abdul Hadi, Asy-Syal. Al-Islamu wa bina'u al-Mujtama' al-Fadhil. Terj. Anshori Umar Sitanggal. Islam Membina Masyrakat Adil dan Makmur. (Jakarta: Pustaka Dian dan Antar Kota) 1987, h. 219.

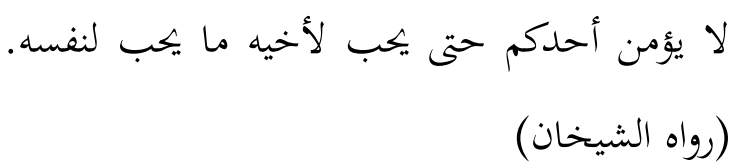

"tidak sempurna iman seseorang hingga ia menyukai bagi saudaranya apa yang ia sukai bagi dirinya".

2. Macam-macam jalinan persaudaraan dalam Islam

Jalinan hati merupakan buah akhlak yang baik, sedangkan perpecahan adalah hasil Akhlak yang buruk ${ }^{9}$. Dari ungkapan ini memberikan arti bahwa Akhlak yang baik akan berimplikasi terhadap tumbuhnya saling cinta, saling sayang, saling menghormati dan saling serasi. Beda dengan akhlak buruk yang justru akan berimplikasi negatif terhadap sesama, mulai dari sifat dengki, hasud dll.

Rasulullah diutus karena untuk menyempurnakan Akhlak. Nabi bersabda : بعثت لأتمم محاسن الأخلاق. رواه أحمد. وصححه

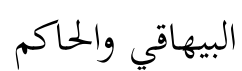

"aku diutus untuk menyempurnakan Akhlak".

Dalam tafsir al-Madhuri karya Muhammad Tsana'ullah al-'Ustmani termaktub sbb:

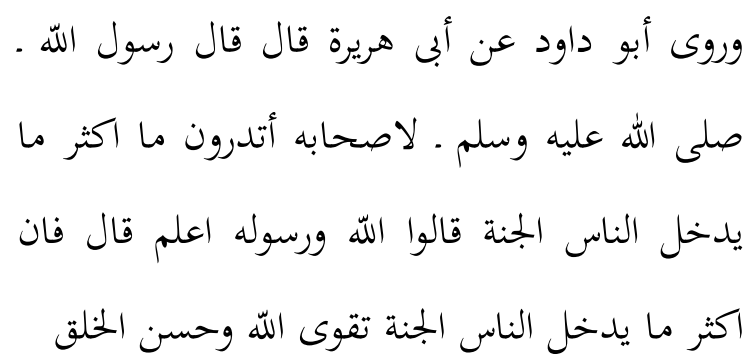

Artinya:

9 Said bin Muhammad Daib Hawwa, AlMusytakhlash Fii Tazkiyatil Anfus. Trj. Ainur Rafiq Shaleh Tamhid, Lc. Mensucikan Jiwa; Konsep Tazkiyatun Nafs Terpadu, (Jakarta : Robbani Press) 2006 Hal. 611 
"Abu Daud meriwyatkan dari Abi Hurairah berkata; berkata rasulullah saw. pada sahabatnya, "apakah kamu sekalian mengetahui hal memasukkan seseorang ke dalam surga? Mereka menjawab "Allah dan Rasul-Nya yang lebih mengetahuinya, selanjutnya beliau bersabda 'sesungguhnya kebanyakan hal yang memasukkan seseorang ke dalam surga adalah taqwa kepada Allah dan Akhlak yang baik' "10

Mind point dalam hadis ini adalah, Taqwa dan Akhlak yang baik. Taqwa merupakan hubungan vertikal terhadap sang khaliq dari makhluknya. Hubungan ini merupakan perintah-Nya karena esensi terciptnya manusia dan seisi alam adalah untuk menyembahnya (taqwa). Sedangkan point yang kedua adalah Akhak, interaksi horizontal merupakan penekanan yang harus diperhatikan. Interaksi horizontal disini adalah jalinan ukhwah Islamiyah dengan sesama umat islam.

Persaudaraan sesama umat Islam sering disebut dengan "ukhuwah Islamiyah". Kata ukhuwah" berasal dari kata "akhun" yang berarti saudara. Sedangkan kata "Islamiyah" berasal dari kata "Islam" yang berarti agama Islam. Berdasarkan terjemah hadis di atas, jelaslah bahwa dalam Islam, persaudaraan (ukhuwah) jika dijaga dengan baik akan menimbulkan kekuatan, selain itu bahwa orang Islam dengan orang Islam lainnya itu bersaudara. Itu artinya kita harus saling tolong, saling asah, saling asih, dan saling asuh. Di antara sesama orang Islam tidak boleh saling dengki, iri hati, benci, saling bertengkar atau saling bermusuhan.

Maka dari itu persaudaraan sesama umat Islam ini harus tercipta agar kehidupan ini menjadi damai, aman,

${ }^{10}$ Tsana'ullah al-'Usmani, Muhammad, Tafsir al-Mudhari, Pakistan: Maktabah Rasyidah, 1425H/ 2004 M Hal. 3987 tentram, dan sejahtera. Ada tiga jenis ukhuwwah (persaudaraan) yang perlu diketahui, yaitu Ukhwah Islamiyah, Ukwah Wathaniyah dan Ukhwah Basyariyah ${ }^{11}$.

\section{Pertama, Ukhuwwah Islamiyah.} Artinya persaudaraan sesama umat Islam. Persaudaraan ini meliputi seluruh negara yang ada orang Islamnya. Artinya selama seseorang adalah muslim walaupun ada di negara Amerika atau Eropa mereka tetap bersaudara, begitu pula di negara lainnya.

\section{Kedua, Ukhuwwah Wathaniyah.}

Artinya persaudaraan sesama satu bangsa/negara. Persaudaraan ini terjadi karena kita satu wilayah/satu negara. Artinya sesama satu negara adalah saudara, baik dia beragama Islam maupun bukan. Mereka juga adalah saudara kita, karena sama-sama satu bangsa (Indonesia).

\section{Ketiga, Ukhuwwah Basyariyah.}

Artinya persaudaraan sesama manusia Persaudaraan ini meliputi seluruh negara dan semua agama yang dipeluk. Hal ini karena kita adalah sama-sama makhluk ciptaan Allah Swt. Hidup di dunia ini tidak bisa sendiri-sendiri. Kita saling membutuhkan satu sama lain. Karena itu jauhkan dan hilangkan rasa atau sikap hidup yang hanya mementingkan keuntungan sendiri, sehingga mengorbankan kepentingan orang lain. Agama Islam sangat mencela sifat mementingkan diri sendiri. Islam menanamkan rasa ukhuwwah basyariyah serta menuntun umatnya untuk memahami bahwa kehidupan ini bukan hanya untuk dirinya sendiri.

Nurkholis Madjid mengkorelasikan keberadaan keimanan dengan rahmat Allah

11 Machendrawaty, Nanih ., modul diklat rumpun bidang pendidikan dan akademik pendalaman materi al-qur'an hadis. Departemen Agama RI Badan Litbang dan Diklat Pusdiklat Tenaga Teknis Keagamaan Jakarta, 2009 Hal. 15 
serta antara rahmat Allah dengan jiwa persaudaraan. Menurutnya, kaum beriman adalah (seharusnya) bersaudara. Persaudaraan itu adalah bentuk paling penting dari ikatan cinta kasih (silaturrahim) atau ukhwah basyariyah antar sesama manusia, sehingga segala permasalahan dan perbedaan tidak akan menjadi prolem dan menjadi kendala bagi kemanusiaan $^{12}$.

Akhlak merupakan hal utama yang harus diperhatikan, baik Akhlak yang sifatnya vertikal maupun horizontal. Dikatakan bahwa, tidak sempurna keimanan seseorang ketika hanya memperbaiki hubungan vertikal dan meninggalkan hubungan horizontal. Hubungan horizontal adalah sebuah ikatan atau jalinan antar sesama sebagaimana disebut diatas. Nabi bersabda :

$$
\begin{aligned}
& \text { المؤمن إلف مألوف ولا خير فيمن لا يألف ولا } \\
& \text { يؤلف. رواه أحمد. وصححه البيهاقي والحاكم }
\end{aligned}
$$

Artinya:

"Orang mukmin adalah jalinan yang dijalin, dan tidak ada kebaikan pada orang yang tidak mau menjalin dan tidak mau dijalin"

3. Pendidikan Ukhuwwah

a. Niat yang lurus

رواه الخمسة عن عمر بن الخطاب عن النبي صلى الله عليه وسلم قال : إنّا الأعمال بالنّيات وإنما لكات

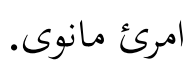

12 Nurcholish. Madjid,, Masyrakat Religius, Jakarta: Paramadina, 2000, h. 29
"Sesungguhnya amalan itu tergantung pada niat dan bagi setiap orang apa yang ia niatkan ${ }^{13}$,

Sebuah amal kebaikan akan menjadi ibadah yang diterima manakala diniatkan dengan niat yang baik, berupa keikhlasan, dan akan menjadi buruk manakala diniatkan dengan niat buruk, berupa ksyirikan -baik kecil apalagi besar-. Akan tetapi seseorang tidak boleh menghalalkan yang haram semata-mata dengan alasan baiknya niat.

b. Memilih saudara yang mukmin dan shalih

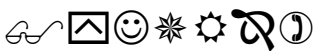

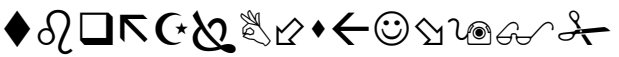

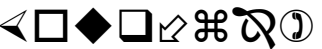

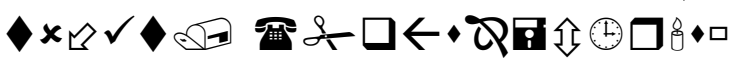

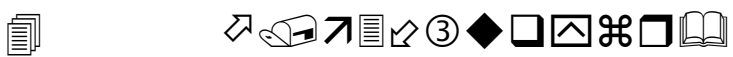

용ㅇ $\square \rightarrow$ (ग) $\square$ es of $\square$

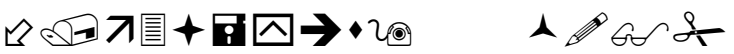

$\checkmark$

Artinya:

Orang-orang beriman itu Sesungguhnya bersaudara. sebab itu damaikanlah (perbaikilah hubungan) antara kedua saudaramu itu dan takutlah terhadap Allah, supaya kamu mendapat rahmat.

$$
\begin{aligned}
& \text { لا تصاحب إلا مؤمنا.... رواه أحمد و أبو داود و } \\
& \text { إبن حبان }
\end{aligned}
$$

Artinya:

"Janganlah engkau bersahabat kecuali dengan orang mukmin"

Hadis ini Rasulallah sampaikan untuk mencegah seseorang berkumpul dengan seseorang yang bisa menyebabkan lemahnya keimanan.

${ }^{13}$ Izzat Daruzah, Muhammad . Tafsir Hadis, Damaskus; Dar Gharb Al-Islami, 1383 H., h. 240 
Dalam kitab Maudhu' al-riddah disebutkan bahwa dengan perintah nabi tersebut diatas kita disarankan untuk berhati-hati dengan segala sesuatu yang bisa mempengaruhi dengan segala daya tipunya termasuk dengan menjadi sahabat. Diistilahkan dengan seseorang yang berkumpul dengan ahli minyak, maka dia akan merasakan harumnya. Bertemanlah dengan dengan orang mukmin yang shaleh $^{14}$.

\section{c. Mencintai karena Allah}

$$
\begin{aligned}
& \text { ثلاثة من كن فيه وجد حلاوة الإيمان : ...... وان } \\
& \text { يحب المرء لا يحبه إلا لله.... }
\end{aligned}
$$

Artinya:

"Tiga perkara yang dengannya seseorang dapat merasakan manisnya iman;

ia mencintai seseorang dan tidaklah ia mencintainya kecuali karena Allah" (HR.Anas).

$$
\begin{aligned}
& \text { فقد روى ابن عباس رضي الله عنهما قال : قال }
\end{aligned}
$$

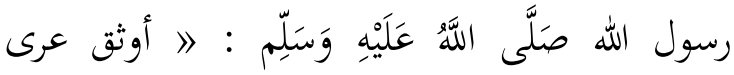

$$
\begin{aligned}
& \text { الإيمان الموالاة في الله والمعاداة في الله والحب في الله }
\end{aligned}
$$

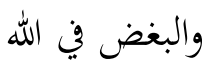

Artinya:

"Telah diriwayatkan dari Ibnu Abbas ra. Berkata: bersabda Rasulullah saw. "Tali iman yang paling kuat: berwala' (loyal) karena Allah, bermusuhan karena Allah,

\footnotetext{
${ }^{14}$ Ali bin Nayif as-Sujud, mausu'ah ar-riddah 'Alaa Madzhabi al-Fikriah al-Mu'asirah (Maktabah Syamilah, tt 2015), h. 197
}

mencintai karena Allah, dan membenci karena Allah ${ }^{15}$."

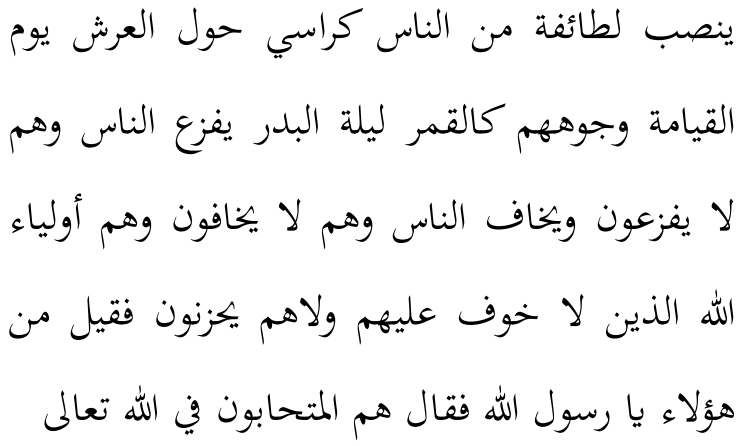

Artinya:

"Disediakan untuk sekolompok orangorang, kursi-kursi disekitar Arsy pada hari kiamat; wajah mereka seperti bulan dimalam kemuliaan, orang-orang merasa cemas tetapi mereka tidak merasakannya, orang-orang merasa takut tetapi mereka tidak merasa takut, mereka adalah para wali Allah yang tidak ada rasa takut pada diri mereka dan tidak merasa bersedih hati. Ditanyakan, Siapa mereka itu wahai Rasulullah? Nabi saw menjawab: mereka adalah orang-orang yang saling mencitai karena Allah."

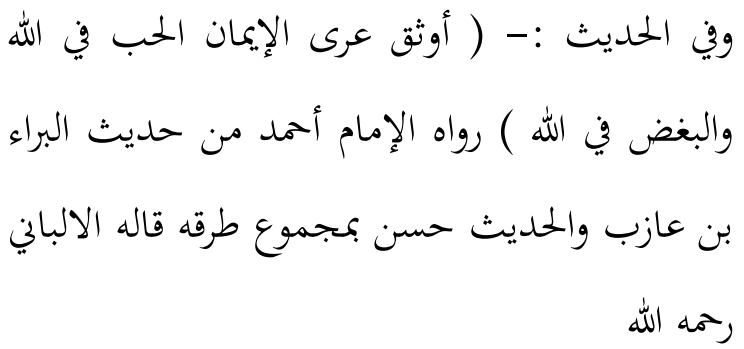

Artinya:

Dalam hadis "Ikatan iman yang paling kokoh adalah cinta karena Allah dan benci karena Allah ${ }^{16}$ ",

Dari beberapa hadis tersebut diatas. Maka, sesuai temanya harus cinta dan

15 Nahbah min Ulama', Ushul al-Iman fii Wudhu'i al-Kitab wa as-Sunnah, (Departemen Agama Kerajaan Saudi: 1421) h. 350

16 Ahmad bin Hamud al-Kholidi, Al-Injad alMu'tamad. Maktabah Syamilah, tt, h. 10 
bahkan benci karena Allah. Cinta karena Allah adalah mencurahkan kasih sayang dan kecintaan kepada orang -orang yang beriman dan taat kepada Allah ta'ala karena keimanan dan ketaatan yang mereka lakukan.

Sedangkan yang dimaksud dengan benci karena Allah adalah mencurahkan ketidaksukaan dan kebencian kepada orang-orang yang mempersekutukanNya dan kepada orang-orang yang keluar dari ketaatan kepadaNya dikarenakan mereka telah melakukan perbuatan yang mendatangkan kemarahan dan kebencian Allah, meskipun mereka itu adalah orangorang yang dekat hubungan dengan kita.

Muhammad Ali al-Hasyimi (2004) menyebutkan, salah satu sifat seorang muslim sejati yang paling istimewa adalah kecintaannya kepada teman-teman dan saudara-saudaranya se-Islam, sebuah cinta yang tak tergantung oleh kepentingankepentingan duniawi dan motif-motif apapun. Cinta ini merupakan merupakan cinta sejati seorang saudara, yang kesuciannya berasal dari sinar tuntunan Islam; pengaruhnya terhadap perilaku umat Islam lainnya cukup unik dalam sejarah hubungan manusia. Cinta inilah adalah cinta yang sebenarnya. Yaitu cinta karena Allah.

4. Hak-hak dan nilai Ukhuwwah (sesama muslim)

Nabi bersabda;

عن أبي هريرة رضي الله عنه قال : قال رسول الله صلى الله عليه وسلم : 》 حق المسلم على المسلم ست ، قيل يا رسول الله وما هن ؟ قال : إذا لقيته فسلم عليه وإذا دعاك فأجبه وإذا استنصحك

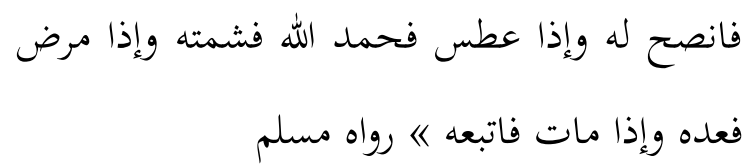

Artinya:

"dari Abi Hurairah ra. Berkata: bersabda Rasulullah saw. Hak Muslim atas Muslim lainnya ada enam. Dikatakan: "apa saja, wahai Rasulullah?" beliau bersabda: Ucapkan salam jika berjumpa dengannya; jika ia mengundangmu, maka penuhilah undangannya; jika ia meminta nasihat kepadamu, maka nasihatilah; jika ia bersin dan memuji Allah; maka ucapkanlah tasymit (yarhamukallah); jika ia sakit, maka jenguklah; dan jika ia meninggal, maka iringilah janazahnya" HR. Muslim ${ }^{17}$.

Dari uraian hadis tersebut diatas Abdullah bin Jaar secara terperinci menjelaskan dari enam poin sabagaimana berikut;

Ketika bertemu saudaranya memanggillah salam karena dengan hal ini akan menumbuhkan rasa kecintaan, sedangkan cinta merupakan kunci dari sebuah keimanan. Nabi bersabda :
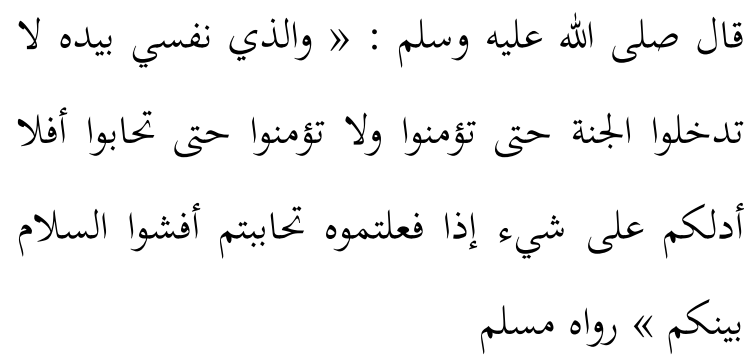

Artinya:

Rasulullah saw bersabda, “ Demi Dzat yang aku berada pada kekuasaannya. Kamu tidak akan masuk surga sehingga kamu beriman, dan kamu tidak beriman sehingga kamu saling kasih mengasihi.

${ }^{17}$ Abdullah bin Jaar Allah, Kamaal al-din alIslami, (Departemen Agama Kerajaan Saudi:1418), h. 75 
Ingat, maukah kamu kalau aku menunjukkan kepada kamu tentang sesuatu yang jika kamu kerjakan tentu kamu akan saling kasih mengasihi?. Syiarkanlah salam di antara kamu”.

Abdullah bin Jaar menyebutkan, Salam merupakan tradisi baik yang berimplikasi positif terhadap persaudaraan umat Islam. Maka seandainya setiap kaum muslimin setiap bertatap muka mereka memanggil salam maka tidak akan ada kebencian diantara mereka, kedamaian antar sesama muslim akan terjalin.

a. Ketika saudaranya memanggil (mengundang) dalam suatu keperluan maka penuhilah sampai ada 'udhur yang sifatnya syar'i. Rasulullah bersabda :

$$
\begin{aligned}
& \text { قال النبي صلى الله عليه وسلم : لا من دعاكم } \\
& \text { فأجيبوه 《) رواه أبو داود والنسائي بسند صحيح }
\end{aligned}
$$

Artinya:

"Rasulullah bersabda : barang siapa memanggilmu (mengundang) maka penuhilah, HR. Abu Daud dan Nasa'i dan sanad yang shahih"

b. Memberikan Nasihat jika saudara kita meminta nasihat. Abdullah bin Jaar menyebutkan, ketika ada saudara meminta nasihat tentang segala hal maka berikanlah nasihat sesuai dengan kemampuan yang dimiliki. Memberikan arahan tentang pekerjaannya. Jika pekerjaannya termasuk pekerjaan yang bermanfaat maka didukung, jika membuatnya tersesat maka diperingati ${ }^{18}$.

c. Nasihat merupakan kewajiban bagi umat muslim kepada semua orang yang membutuhkannya, karena islam adalah nasihat. Sebagaimana Rasulullah bersabda :

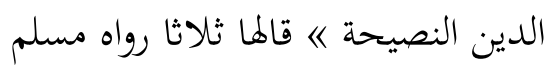

"Agama adalah nasihat. Nabi mengulang sampai tiga kali. HR. Muslim ”

d. Jika saudara kita bersin dan memuji Allah maka kita mengucap "yarhamukallah" Bersin adalah keluarnya udara yang keras, kuat disertai dengan hentakan melalui dua lubang; hidung dan mulut. Maka akan terkuras dari badan bersamaan dengan bersin ini sejumlah hal seperti debu, dll. Jadi dapat diartikan bahwa bersin itu mengeluarkan penyakit dan itu merupak tabi'at yang datangnya dari Allah. Maka dari dari itu, rasa syukur orang yang bersim ini melafalkan pujian dan harus dijawab oleh yang lain dengan lafal yarhamukallah

e. Jika ada saudara yang sakit, maka menjenguknya. Abdullah bin Jaar menyebutkan, bahwa menjenguk orang sakit ini merupakan pekerjaan mulia yang diajarkan oleh Islam. Apalagi yang sakit adalah saudara, keluarga dekat dan tetangga. Rasulullah bersabda ;

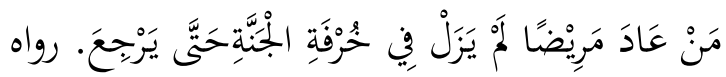

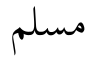

Artinya:

"Barangsiapa yang menjenguk orang yang sedang sakit, maka dia senantiasa berada pada petikan buah kurma di dalam surga sampai dia pulang" (HR. Muslim)

f. Jika ada saudara kita meninggal, maka iringilah janazahnya. Merupakan hak seorang muslim atas muslim yang lain 
adalah mendampingi janazah saudaranya yang meninggal. Abdullah bin Jaar mengatakan, dan mengutip dari dhadis nabi; seorang muslim yang mendampingi janazah saudaranya sampai men-shalatinya maka dia akan mendapat satu kebaikan, dan jika mendampinginya sampai mensemayamkannya maka dia akan mendapatkan dua kebaikan, yang satu kebaikan itu diibaratkan dengan gunung emas yang sangat besar ${ }^{19}$.

Ada tiga orang yang terpenuhi haknya dalam hal ini. Yaitu, hak Allah, hak saudaranya yang meninggal (mayit), dan hak keluarganya yang ditinggal.

Selain hak-hak tersebut diatas, ada banyak hak-hak lain yang harus diperhatikan dalam hubungan persaudaraan. Diantaranya hadis Nabi

g. Bersama-sama merasakan kegembiraan ataupun kesediahan

$$
\text { المؤمن للمؤمن كلبنيان يشد بعضه بعضا }
$$

Artinya:

"Mukmin dengan Mukmin lainnya ibarat sebuah bangunan yang saling menguatkan satu sama lain" HR. Bukhari dan Muslim dari Abu Musa.

h. Menolak menghibahi saudaranya

من ذب عن لحم أخيه بالغيبة كان حقا على الله أن

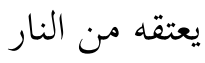

Artinya:

"Barang siapa membela kehormatan saudaranya yang menghibahi saat ia tidak

\footnotetext{
${ }^{19}$ Abdullah bin Jaar Allah, Kamaal al-din..., h.
}

berada di disisinya, maka atas Allah untuk membebaskannya dari api Neraka”

i. Menolong karena Allah

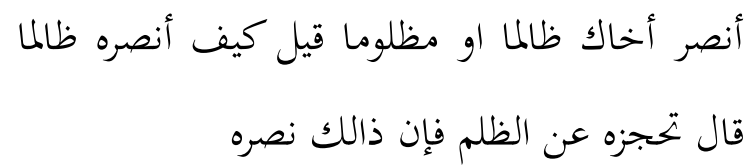

Artinya:

"Tolonglah saudaramu yang dzallim dan yang terdzalimi. Dikatakan, "bagaimana aku menolongnya sedang ia berbuat dzalim?" belliau menjawab" "hendaklah engkau mencegahnya dari perbuatan dzalim. Itulah cara menolongnya"

j. Tidak meminang pinangan saudaranya

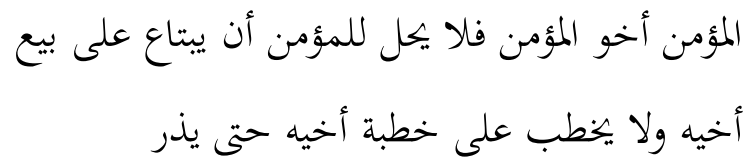

Artinya:

"seorang mukmin adalah saudara bagi mukmin lainnya. Maka tidak halal bagi seorang mukmin berjual beli diatas jual beli saudaranya dan janganlah meminang pinangan saudaranya hingga ia meninggalkannya."

5. Pendidikan dalam memilih Ukhuwwah dalam masyarakat multikultural

Perlu diketahui, bahwa tidak setiap orang pantas dijadikan teman, ataupun saudara.

$$
\text { المرء على دين خليلة فلينظر احدكم من يخالل }
$$

Artinya:

"Seseorang itu dapat dinilai menurut keadaan (kebiasaan) temannya, maka hendaknyalah salah seorang kamu 
memperhatikan siapa yang akan ditemaninya."

Maka, hendaklah orang yang akan dipilihnya sebagai teman itu memiliki perangai dan sifat yang istemewa, yang akan membuat perkawanan itu menyenangkan. Secara garis besar, hendaklah ia seorang yang berakal, bagus pekert, tidak fasik da tidak tamak terhadap dunia $^{20}$.

Akal adalah pokok segala sesuatu yang menjadi modal utama. Maka tidak ada gunanya berkawan dengan orang bodoh,. Karena hanya akan mengakibatkan kebencian dan terputusnya hubungan, meski telah berlangsunglama. Ada yang berpendapat bahwa tidak bersaudara dengan orang bodoh merupukan salah bentuk pendekatan diri pada Allah.

Pekerti yang baik jelas sangat diperlukan, karena sama sekali tidak ada kebaikan bersaudara/berteman dengan orang yang selalu dikalahkan oleh kemarahan, shahwat, dan kepengecutan, serta senantiasa selalu memperturutkan hawa nafsunya.

Selanjutnya Syekh Jamaluddin (1993:276) menjelaskan bahwa, orang fasik yang terus menerus kefasikannya, juga tidak patut dijadikan teman/saudara, dan tidak ada gunanya. Bahkan dengan menyaksikan kefasikan itu dapat memperingan perkara maksiat dalam dirinya, dan merusak keberpalingan hati dari padanya. Disamping bahwa orang yang tidak takut kepada Allah itu tidak dapat dipercaya pola kebenaran dan ketulusan persaudaraannya. Bahkan, hal itu

20 Djamaluddin, Muhammad Syekh. Mauidhotul Mukminin min Ihya' Ulumuddin. Trj. Abu Ridha. Semarang: CV Asy-Syafi'i, 1993, h. 275 akan berubah-ubah sesuai dengan perubahan tujuan dan kepentingannya ${ }^{21}$. Allah berfirman : Al-Kahfi/08:28

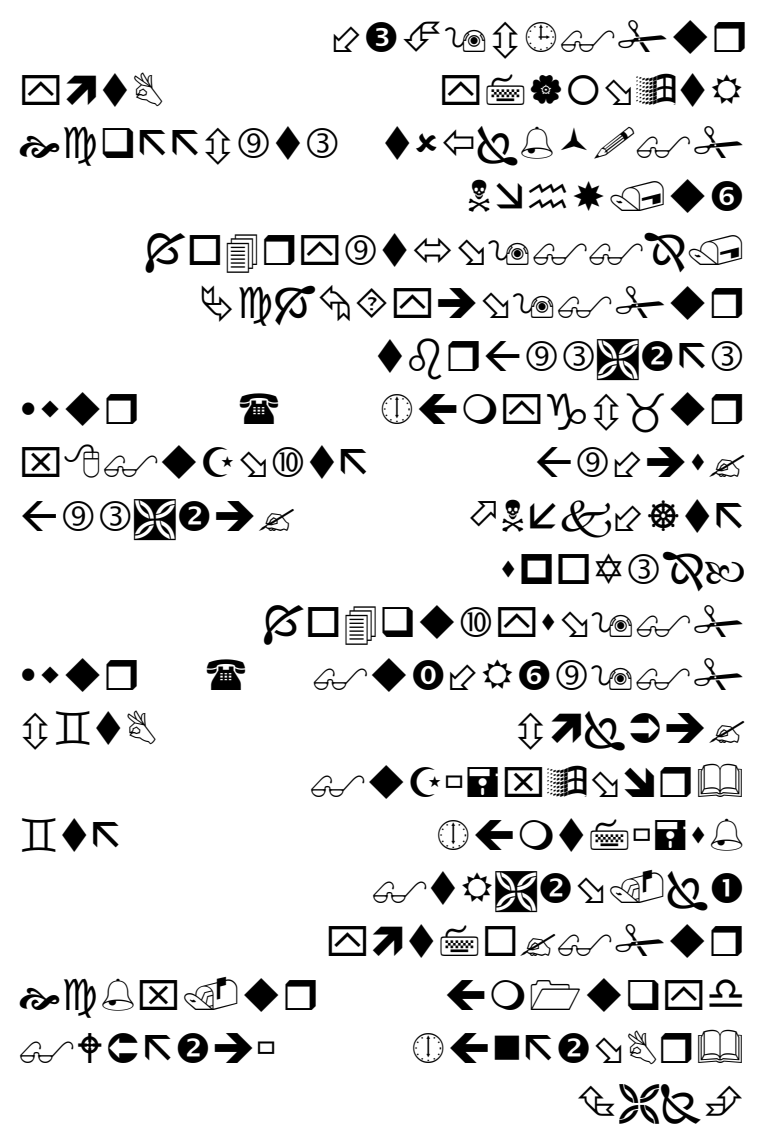

Artinya:

"Dan Bersabarlah kamu bersama-sama dengan orang-orang yang menyeru Tuhannya di pagi dan senja hari dengan mengharap keridhaan-Nya; dan janganlah kedua matamu berpaling dari mereka (karena) mengharapkan perhiasan dunia ini; dan janganlah kamu mengikuti orang yang hatinya Telah kami lalaikan dari mengingati kami, serta menuruti hawa nafsunya dan adalah keadaannya itu melewati batas".

Al-Maidah/05: 29

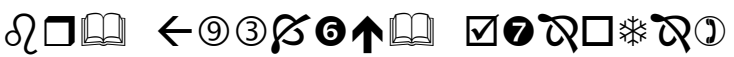

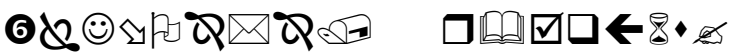

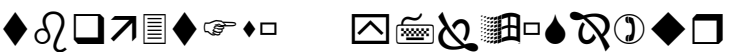




\section{है 86 as $\square$ 206 \&

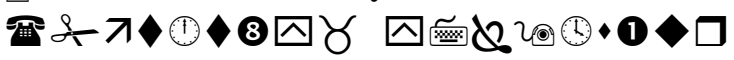

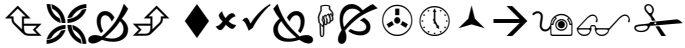

Artinya:

"Sesungguhnya Aku ingin agar kamu kembali dengan (membawa) dosa (membunuh)ku dan dosamu sendiri, Maka kamu akan menjadi penghuni neraka, dan yang demikian Itulah pembalasan bagi orang-orang yang zalim."

Al-Luqman/31:15

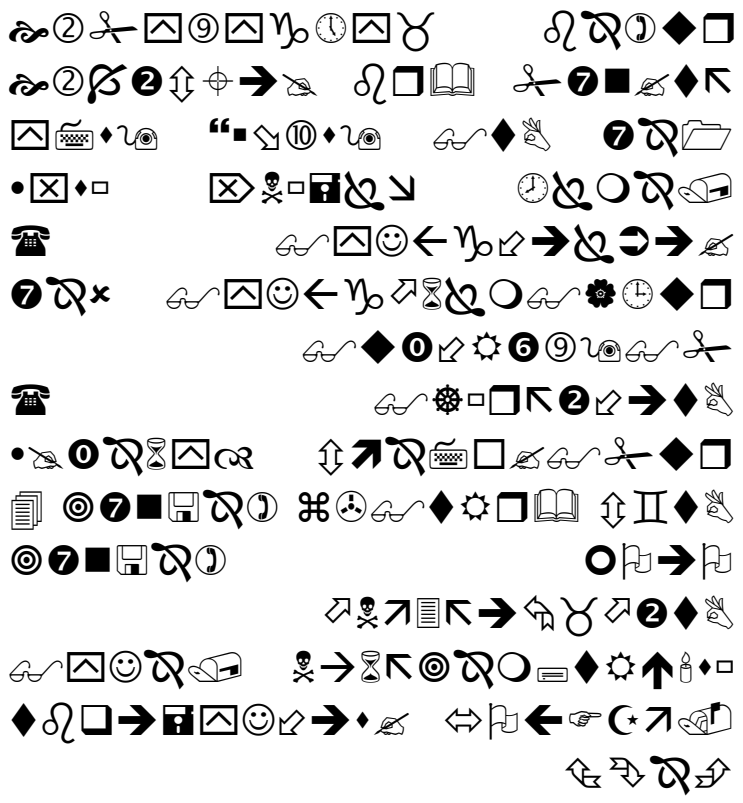

Artinya:

"Dan jika keduanya memaksamu untuk mempersekutukan dengan Aku sesuatu yang tidak ada pengetahuanmu tentang itu, Maka janganlah kamu mengikuti keduanya, dan pergaulilah keduanya di dunia dengan baik, dan ikutilah jalan orang yang kembali kepada-Ku, Kemudian Hanya kepada-Kulah kembalimu, Maka Kuberitakan kepadamu apa yang Telah kamu kerjakan".

Dari berbagai ayat tersebut diatas dapat disimpulkan menjadi sebuah anjuran untuk bergaul dengan seseorang sebagai berikut: a. Orang apabila engkau memberikan kebaikan padanya, ia suka menerimanya dengan senang hati. Jika melihat kebaikan darimu, ia menyebutnyebutnya dan jika ia melihat keburukan darimu ia menutupnya.

b. Orang yang apabila engkau meminta sesuatu padanya, dia memberimu. Jika engkau diam, ia menyapamu. Jika enkau tertimpa musibah, ia menghibur dan menolongmu.

c. Orang yang apabila engkau berkata, ia membenarkan perkataanmua. Jika engkau mencoba mengusahakan sesuatu, ia menolongmu. Dan jika engkau bersengketa dengannya ia mengalah untukmu.

Syekh Jamaluddin selain merujuk terhadap ayat al-Qur'an diatas, dia juga merujuk terhadap perkataan Ali bin Abi Thallib dan Abu Sulaiman Ad-Darani.

Ali bin Abi Thallib berkata: temanmu yang sebenarnya adalah orang yang bersamamu, yang mau mengambil resiko untuk kepentinganmu, dan menjelaskan serta menghilangkan semua kebimbangnmu. Dia kerahkan segala upaya dan tenaga untuk berkumpul denganmu ${ }^{22}$.

Abu Sulaiman ad-Darani juga berkata : janganlah engkau pergauli kecuali salah satu dari dua orang; seseorang yang dapat engkau mintai pertolongan dengan urusan duniamu, atau seseorang yang engkau dapat menambahkan dan memperoleh kemanfaatan dengannya dalam urusan akhiratmu.

Jadi, berteman dengan kedua orang ini merupakan kebodohan dan kesia-siaan belaka. Maka dari itu slektifitas hubungan sangat dianjurkan. Maka pantaslah ketika dalam kajian kitab-kitab salaf anjuran

\footnotetext{
${ }^{22}$ Djamaluddin, Muhammad..., h. 278
} 
untuk berteman dan bersaudara dengan para ulama dan fuqaha demi mengambil hikmah dan ilmu dari keduanya.

Maka dalam hal ini menarik jika merenungi ucapan luqman terhadap anaknaya "wahai anakku, pergauilah para ulama dan rapatilah mereka dengan kedua lututmu, karena sesungguhnya hati itu hidup dengan santapan hikmah. Sebagaimana tanah yang mati terjadi hidup dengan curahan air hujannya"

\section{KESIMPULAN}

Dari pemaparan tersebut ditas, dapat penulis simpulkan bahwa, Pendidikan ukhuwah islamiyah dalam mencipatakan perdamaian pada masyarakat multikultural harus dilakukan semata-mata karena ingin memmperoleh keuntungan-keuntungan ukhrawi melalui orang yang dicintainya itu, dan inilah petunjuk nabi sesungguhnya tentang persaudaraan. Karena tidak bisa dipungkiri persaudaraan yang terjalin pada zaman saat ini lebih menitikberatkan pada pragmatisme sesaat, sehingga persaudaraa itu bukan dijalani dengan rasa kasih sayang yang abadi.

Banyak hadis nabi yang menyuruh kita (umatnya) untuk meluruskan hati serta mencitai saudara kita hanya karena Allah, karena itu merupakan adab dalam menjalin sebuah persaudaraan dalam masyarakat multikultural. Persaudaraan (ukhuwah) ada tiga macam yaitu: Ukhuwah Islamiyah, Ukhuwah Wathaniyah, dan Ukhuwah Basyariyah.

Persaudaraan adalah jalinan, jalinan dari dua orang yang berbeda, sebagimana jalinan suami istri maka menuntut sejumlah hak yang harus dipenuhi. Karena itu saudara mempunyai hak yang harus dipenuhi oleh saudara yang lain. Atara lain:

1. Memberikan salam jika bertemu
2. Memenuhi undangan jika diundang olehnya

3. Memberikan Nasihat jika diminta

4. Jika bersin dan memuji Allah maka membalas dengan do'a "yarhamukallah"

5. Jika sakit, maka menjenguknya.

6. Jika meninggal, maka mengiringi janazahnya.

7. dll

Pemenuhan terhadap hak tersebut harus dilalui dengan penuh kasih sayang dan keikhlasan, sehingga jalinan itu menjadi jalinan yang abadi serta di ridhoi oleh Allah. Namun mencapai status abadi tersebut sedikit sulit tercapai jika cara mencari saudara tidak tepat. Maka, Islam memberikan arahan sifat-sifat yang harus dimiliki seseorang yang akan dijadikan saudara tersebut yaitu diantaranya ; Berakal bagus, bagus pekerti, tidak fasik dan tidak tamak harta.

\section{DAFTAR PUSTAKA}

Abdullah bin Jaar Allah, Kamaal al-din alIslami, Departemen Agama Kerajaan Saudi:1418

Abdul Aziz bin Fathi as-Sayyid Nada, Mausu'atul Aadaab al-Islamiyah. Trj. Abu Ihsan al-Atsari, Ensiklopedi Adab Islam Menurut al-Qur'an dan al-Sunnah, PT. Pustaka Asy-Syafi'i, 2007

Ahmad bin Hamud al-Kholidi, Al-Injad alMu'tamad. Maktabah Syamilah, $1436 \mathrm{H}$

Ali bin Nayif as-Sujud, mausu'ah arriddah 'Alaa Madzhabi al-Fikriah al-Mu'asirah tt. Maktabah Syamilah, 2011

Al-Ghazali, Mukhtashar Ihya' Ulumuddin, Terj. Irwan Kurniawan, Bandung: PT. Mizan Pustaka, 2008 
Asy-Syal, Yusuf Abdul Hadi, Al-Islamu wa bina'u al-Mujtama' al-Fadhil. Trj. Anshori Umar Sitanggal. Islam Membina Masyrakat Adil dan Makmur. Jakarta: Pustaka Dian dan Antar Kota, 1987.

Aziz, Zahid Islam peace and tolerance (Ahmadiyya Anjuman Lahore Publications, U.K. 2007),

Djamaluddin, Muhammad Syekh. Mauidhotul Mukminin min Ihya' Ulumuddin. Trj. Abu Ridha. Semarang: CV Asy-Syafi'i, 1993

Departemen Pendidikan Nasional, Kamus Besar Bahasa Indonesia, 1996

Hawwa, Said, Al-Mustakhlash Fi Tazkiyatil-Anfus. Trj. Tim Kuwais, Tazkiyatun Nafs. Jakarta: Pena Pundi Aksara, 2006

Haryati, Tri Astutik Islam Dan Pendidikan Multikultural (Tadrîs. Volume 4. Nomor 2. 2009

Izzat Daruzah, Muhammad . Tafsir Hadis, Damaskus; Dar Gharb Al-Islami, $1383 \mathrm{H}$

Madjid, Nurcholish Dr. Masyrakat Religius, Jakarta: Paramadina, 2000

Machendrawaty, Nanih Hj. M.Ag., modul diklat rumpun bidang pendidikan dan akademik pendalaman materi alqur'an hadis. Departemen Agama RI Badan Litbang dan Diklat Pusdiklat Tenaga Teknis Keagamaan Jakarta, 2009

Nahbah min Ulama', Ushul al-Iman fii Wudhu'i al-Kitab wa as-Sunnah, Departemen Agama Kerajaan Saudi: 1421

Rutanto, Bambang Masyarakat Multikultural di Indonesia (Bandung: PT Remaja Rosdakarya, 2016

Rahman, Mufiqur Demokrasi dalam filsafat pendidikan Islam dan Barat (Malang :Unisma). 2017
Said bin Muhammad Daib Hawwa, AlMusytakhlash Fii Tazkiyatil Anfus. Trj. Ainur Rafiq Shaleh Tamhid, Mensucikan Jiwa; Konsep Tazkiyatun Nafs Terpadu, Jakarta : Robbani Press, 2006

Sayyid Murtadla al-Ridlawi, Fi Sabi LilWahdah al-Islamiyah, Trj.

Mohammad Thohir. Membina Kerukunan Muslimin, Jakarta: PT. Dunia Pustaka, 1984

Tsana'ullah al-'Usmani, Muhammad, Tafsir al-Mudhari, Pakistan: Maktabah Rasyidah, 1425H/ 2004 M 